\title{
A Phonological Contrastive Analysis of Kurdish and English
}

\author{
Massoud Rahimpour (Corresponding author) \\ The University of Tabriz, Iran \\ $\&$ \\ The University of Queensland, Australia \\ E-mail: rahimpour2011@gmail.com \\ Majid Saedi Dovaise \\ Office of Education, Sannandaj, Iran \\ E-mail: saedidovaise@yahoo.com
}

Received: November 17, $2010 \quad$ Accepted: December 15, $2010 \quad$ doi:10.5539/ijel.v1n2p73

\begin{abstract}
This study is an attempt to compare and contrast the sound systems of Kurdish and English for pedagogical aims. The consonants, vowels, stress and intonation of the two languages are described using the same model-taxonomic phonology- and then compared and contrasted to find the similarities and differences between the two systems and hence the potential areas of difficulty in teaching English to students whose native language is Kurdish. Forty four phonemes of BBC English have been described and compared with the thirty eight phonemes of Sorani Kurdish. The nature and function of stress and intonation in the two languages have also been compared and contrasted.
\end{abstract}

Keywords: Phonology, Sound system, Contrastive analysis, Kurdish language

\section{Introduction}

Contrastive phonology is 'the process of comparing and contrasting the phonological systems of languages to formulate their similarities and differences (Yarmohammadi; 1995:19). It is in the area of phonology that as Ringbom (1994:738) claims "the predictions of CA work best". A contrastive analysis project involves two steps: describing each of the languages (within the same model) and juxtaposition for comparison (James, 1980). The choice of model is somehow straightforward in phonology since we have basically two choices: taxonomic phonology and generative phonology. The former model has been adopted here because it is more suitable "for phonological CA, particularly in applied areas" as Yarmohammadi (1996) asserts. Kohler (1971) admits that taxonomic approach works quite well where the concern is "to put contrastive studies and their practical applications in language teaching on a better foundation".

Despite the many criticisms geared at CA the two basic tenets of it have survived: L1 is a major factor in L2 learning and important insights can be gained from the comparison and contrast of two languages (Ringbom, 1994; Ellis, 2008). Fallahi (1991) also advocates that "the application of CA for English programs has to be a matter of great importance in Iran because the L1 interference is quite noticeable in an EFL environment". Johnson and Johnson (1999:86) also claim that "recent years have seen some revival of interest in CA though sometimes under new names".

Phonological CA is even more justifiable to be conducted since as Cook (1999:86) states CA is "most successful in the area of pronunciation", Felix (1980) speculates that at the phonological level L2 learners start with their L1 system (quoted in Ioup, 1984). It has been suggested that "studies of SLA have tended to imply that CA may be most productive at the level of phonology" (Richards; 1984: 204).

At the theoretical level this study gives a picture of the sound system of Kurdish and it also demarcates the differences and similarities of the Kurdish sound system and that of English. Pedagogically the results can be processed to be used in teaching pronunciation, material development, and testing.

\section{Literature review}

In a broad sense Contrastive Analysis has always been present in linguistics and language teaching materials (Robins, 1997; Stern 1983; Johnson and Johnson, 1999; Brown, 2000; Yule, 2006; Fasold \& Connor-Linton 2006; Ellis, 2008; Ranta, 2010). Teachers have always accepted the idea that the native language affects second language acquisition (Odlin, 1989). However, it was the structural linguists of the 1940s and 1950s who promoted the term Contrastive Analysis and paid due attention to the relevance of linguistic description in 
general and contrastive descriptions in particular for language teaching (Cook, 1999). Among these linguists Fries (1945 ), Weinreich (1953) and Lado (1957) are usually mentioned in the literature on CA. Lado's book inspired an eruption of activity in contrastive analysis and the 1960s saw numerous research projects and publications ( Stern, 1983 ). Within the theoretical framework of CA some scholars tried to extend its use beyond the word and sentence. Kaplan (1966) proposed that contrastive studies were possible beyond the sentence level, and his arguments encouraged the study of what is now frequently termed contrastive rhetoric (Odlin, 1989; Nunan, 2001). Later with the increased interest in discourse from the 1970s onward CA extended to areas such as politeness, apologies and so forth (Hartman, 1980). CA was also extended to generative linguistics and Di Pietro's Language Structures in Contrast (1971) was a reinstatement of CA based on generative linguistics and hence is of great theoretical interest (Sanders, 1981). Krzeszowski's contrastive generative grammar (1974) is another important landmark in the history of contrastive theory (Keshavarz, 1994; Sajavaara, 1981).

However, the criticisms on CA did not destroy its original basic idea that L1 is a major factor in the process of L2 learning, but they showed that the original approach to CA was too narrow and needed to be expanded in many various directions (Ringbom, 1994). The expansion of CA led to the developments of error analysis, contrastive discourse, and contrastive pragmatics.

The extension of CA continued in the 1980s: the interests in parameter setting in Chomskyan linguistics, contrastive pragmatics based on the statements of universal principles to elucidate different realizations (Thomas, 1983), contrastive rhetoric hypothesis which proposes that 'different speech communities have different ways of organizing ideas in writing' (Kachru, 1995; Chen, 1997) are some other examples of the expansion of CA.

Many language teachers still find CA useful, especially in phonology. Transfer is present in phonology more than any other area and it is because of this fact that one can guess the first language of a speaker through his/her accent while speaking a second language. Iranian scholars have tried to compare and contrast various aspects of Persian with those of English. These include concise CA sketches to thorough analyses. Mirhassani (1983) tried to explain pronunciation problems of Iranian students learning English. Since the source of problems lies in the differences between the two languages, exercises which are based on a careful contrastive analysis are the best for the teaching of pronunciation he concluded.

The Kurdish language is spoken approximately by forty million people living mainly in Turkey, Iran, Iraq and Syria. Kurdish is a member of the Indo-Iranian branch of the Indo-European languages. It is regarded as a northwestern Iranian language (Bright, 1992; Asher \& Simpson, 1994). The Kurds are ancient people; however, modern literary Kurdish began in Iraq in 1919, when Kurdish became the language of instruction in public schools in Kurdish areas. There is today a rich and flourishing literature in Iraq, where Kurdish intellectuals have established a Standard Literary Kurdish essentially based on Sorani dialect. The same dialect has also been adopted and used by the Kurds in Iran since the 1940s, though it was suppressed during the years 1947 to 1979 by the government. According to Wikipedia (2010) it is also pointed out that Kurdish has two standardized versions, which have been labeled 'Northern' and 'Southern'. The northern version, commonly called Kurmanji, is spoken in Turkey, Syria and northern part of the Kurdish-speaking areas of Iraq and Iran, and it accounts for a little over three-quarters of all Kurdish speakers. The central version, commonly called Sorani, is spoken in west of Iran and much of Iraqi Kurdistan (see also Abdullah and Alam, 2004).

The first classification of the Kurdish dialects was prepared by Sharaf Khan Bedlisi (1543-1603) who divided Kurdish into four dialects of Kurmanji, Goran, Lur, and Kalhor. Based on this categorization Tawfiq Wahby provided another classification earlier in the twentieth century. Wahby divided Kurdish into three main dialects of Kurmanji (northern and southern), Gorani, and Luri (Khaznadar, 2001). Nabaz (1976) believes that there are four dialects and following him Kurdish dialects are usually put into three main groups: northern, central, and southern.

Roughly speaking northern Kurdish, often called Kurmanji, is spoken by the Kurds in Turkey, Syria, in Iraq to the north of the Greater Zab River and in some northern parts of the Kurdish-speaking areas in Iranian west Azarbaijan. The central dialect of Kurdish, generally referred to as Sorani, is spoken in Iraq, in the Iranian province of Kurdistan and in southern parts of Iranian west Azarbaijan. It is written in an adapted version of the Arabic alphabet. In the twentieth century written Sorani has had more opportunities to develop than Kurmanji, and a richer modern literature now exists in this dialect. In this paper the word Kurdish refers to Sorani for this is the standard dialect among the Kurds in Iran and Iraq. The southern dialect of Kurdish includes the Kurdish of Kermanshah and its neighboring Kurdish areas within Iran and Iraq.

Kurdish is a phonetic language i.e. it is written as it is pronounced. Its orthography is based on Arabic script; diacritic marks and dots are used to represent consonants and vowels not found in Arabic. All phonemes are represented by full letters, except for $/ \mathrm{i} /$, which is not represented at all (Mc Carus, 1992).

During the late nineteenth and the early of twentieth century Kurdish had variously been compared and contrasted with Arabic and Persian. At first these comparisons aimed at establishing a standard alphabet for the 
Kurdish language by finding the sounds which are present in Kurdish but absent in those two languages and vice versa. Later the same approach was adopted by the Kurdish scholars who tried to elaborate on grammar of the language.

In 1892, Yussif Ziaddin found that in addition to the Arabic vowels Kurdish has two more vowels that is open /o/ and open /i/. In 1926 Ahmad Aziz Agha noticed that in addition to Arabic /1/ and /r/ Kurdish has the velarized or dark $/ 1 /$ and the trill or roll $/ \mathrm{r} /$ as two independent phonemes and not as two allophones of $/ 1 /$ and $/ \mathrm{r} /$. In 1923 Wahby showed that there is a /i/ sound in Kurdish (the same as schwa in English), but there is no letter for it in the alphabet. Saeed Sedqi (1928) also paid attention to this sound in his concise syntax of Kurdish (Khaznzdar, 2002). Ghazi Fateh Wais (1984) prepared the (first) comprehensive phonetics of Kurdish. Throughout his book he used contrast and comparison as a tool for clarifying some aspects of Kurdish sound system: He noticed that Kurdish has eight vowels while English has twelve (without counting diphthongs). As for consonants the number was twenty seven in Kurdish and twenty four in English. Wais also compares and contrasts syllable structure and stress of the two languages. Abdulhamid Jacub (1993) tried to compare and contrast the sound system of Kurdish with that of English to establish a better foundation for the teaching of English pronunciation at the primary stage. He shed light on the phonetic differences between the apparently shared sounds (phonemes) of the two languages.

\section{Consonant system of Kurdish}

\subsection{Stops}

There are nine stop phonemes in Kurdish. They are / p, b, t, d, k, g, q , , ,? /. The three phonemes of / b, d, g / are voiced and the rest are voiceless. Voiceless stops are aspirated in almost all positions. $/ \mathrm{p} / \mathrm{and} / \mathrm{b} / \mathrm{are}$ bilabial, /t/ and /d/ dental-alveolar, /k/ and /g/ velar, /q/ post-velar (or uvular), / $\varsigma /$ pharyngeal, and / ?/ is glottal. / $/ \mathrm{k} /$ and $/ \mathrm{g} /$ are heavily palatalized before high vowels, where they contrast with the affricates. These voiceless stops can have unreleased allophones in final position. They are almost in free variation with the aspirated forms. The aspiration is more strong in $/ \mathrm{p} /$ and less evident in $/ \mathrm{q} /$ and $/ \mathrm{\varsigma} /$. As for allophones $/ \mathrm{d} /$ is devoiced in final position e.g. šâd (happy)./t/ is palatalized specially after the velarized /1/ in words like gâlta (joke) and salta (vest). /q/ and / $/$ / appear primarily in Arabic loans. / ?/ occurs only word initially. It is either deleted or changed into / $/$ / when it occurs as a member of a consonant cluster e.g. al?ân is pronounced as alçân (now) and mas?ūl as masūl (the person in charge). The occurrence of /?/ is predictable initially: whenever a syllable does not start with other consonants, it is supposed to begin by /?/ since no syllable starts with a vowel.

\subsection{Fricatives}

The ten fricative phonemes of Kurdish include : / f, v, s , z, ̌s , ̌ , x , $\gamma, \hat{\mathrm{h}}, \mathrm{h} / . / \mathrm{v}, \mathrm{z}, \check{\mathrm{z}}, \gamma /$ are voiced and the rest voiceless. /f , v / have labio-dental, / s, z / dental-alveolar, /̌s , ž / alveo-palatal, /x, $\gamma$ / velar, /h/ / pharyngeal and $/ \mathrm{h} /$ has glottal articulation. $/ \mathrm{v} /$ has a low frequency in Sorani Kurdish. $/ \mathrm{s} /$ is pharyngealized in words like sag (dog) and sad (hundred) (Mc Carus, 1992; Wais, 1984). So /s/ has two allophones, though this pharyngealized allophone is not of high frequency. $/ \gamma /$ and $/ \hat{h} /$ mostly appear in Arabic loans. The sound $/ \mathrm{h} /$ rarely occurs word finally. Voiced fricatives, like voiced stops, can become devoiced finally.

\subsection{Affricates}

There are two affricate phonemes in Kurdish: /č/ and /j/. The first is voiceless and the second is voiced. They have an alveo-palatal articulation; however, these two sounds are heavily palatalized in Kurdish and because of this even some authors have classified them as palatal phonemes (Wais, 1984; Mc Carus, 1992). /č/ becomes unreleased in final position. $/ \mathrm{j} /$ can become devoiced finally.

\subsection{Nasals}

There are three nasal sounds in Kurdish: / m, n, y / ( Karimi, 1994 )./p/ cannot be regarded as an allophone of /n/ since the minimal pairs like han (they exist) vesus hay (honeybee) and bân (roof) vesus bây (to call out) show its meaning-distinguishing feature, though some authors have claimed so (Rokhzadi, 2000; Wais, 1984). The phoneme $/ \mathrm{y} /$ never occurs initially. / $\mathrm{m}, \mathrm{n}, \mathrm{y} /$ have bilabial, alveolar, and velar articulation respectively. $/ \mathrm{n} /$ becomes dental-alveolar before dental-alveolar and labiodental sounds. Before bilabial sounds the contrast between $/ \mathrm{m} /$ and $/ \mathrm{n} /$ is sometimes lost and become neutralized e.g. barânbar and barâmbar (equal).

\subsection{Laterals}

There are two lateral phonemes in Kurdish: / 1, í. They have alveolar and palatal articulations (and they are clear and velarized respectively). Minimal pairs like gul (leprosy) versus gul (flower) and čil (forty) versus čí (branch) illustrate the fact that these two sounds are two independent phonemes (and not two allophones of one phoneme as it is the case in English). /í/ never occurs initially. Both /1// and /í/ are voiced.

\subsection{Retroflexes}

Kurdish has two retroflex sounds: / $\mathrm{r}, \check{\mathrm{r}}$ /. They have alveolar and alveo-palatal articulation respectively and both are voiced. $/ \mathrm{r} /$ is flap (tap): it is produced by making a single tap of the tongue. $/ \check{\mathrm{r}} /$ is trill (roll): it is produced by 
a series of taps by the tongue. For the meaning-distinguishing feature of these two phonemes one can notice the contrast between the minimal pairs bar (the front part) versus bař (a kind of coarse carpet) and drâw (money) versus dřâw (ragged). The tap /r/ never occurs initially. The trill one can occur in all three positions: initially, medially and finally.

\subsection{Glides (semivowels)}

The two glides that are present in Kurdish are $/ \mathrm{w} /$ and $/ \mathrm{y} /$. The former has bilabial and the latter palatal articulation. In Persian $/ \mathrm{w} /$ is not a segmental phoneme but rather a derived form of an underlying $/ \mathrm{v} /$, though it is a phoneme of high occurrence in Kurdish. There is only a tendency in Kurdish to pronounce $/ \mathrm{v} /$ as $/ \mathrm{w} /$ resulting in mispronouncing very as /weri/ and vest as /west/ by the Kurdish learners of English. Most of the words which have a $/ \mathrm{v} /$ sound in northern dialect of Kurdish are pronounced with changing $/ \mathrm{v} /$ into $/ \mathrm{w} /$ in Sorani Kurdish (Nabaz, 1979). Phonetically /w/ and /y/ are vowels, but phonologically they are consonants. Both can occur as the second member of phonemic diphthongs: /ay/ in dayk (mother) and aw in čaw (eye).

\section{Consonant System of English}

The accent of English which has been selected for this study is the accent often called Received Pronunciation or BBC Pronunciation. It is the accent that is most often recommended for foreign learners studying British English and has always been chosen by teachers who teach to foreign learners, and is the accent that has been most fully described and has been used as the basis for pronouncing dictionaries (Roach, 2000). This accent has twenty four consonantal phonemes.

\subsection{Stops}

English has six stops: / p, t, k, b, d, g/. The glottal stop /?/ occurs frequently, but it is often an alternative pronunciation of $/ \mathrm{p} /, / \mathrm{t} /, / \mathrm{k} /$ in certain contexts. Voiceless stops are aspirated in an initial position. In initial position $/ \mathrm{b}, \mathrm{d}, \mathrm{g} /$ cannot be preceded by any consonants, but $/ \mathrm{p}, \mathrm{t}, \mathrm{k} /$ may be preceded by $/ \mathrm{s} /$ : in this case they become unaspirated. In final position voiced stops become devoiced. The vowels preceding $/ \mathrm{p}, \mathrm{t}, \mathrm{k} /$ are much shorter ( Roach, 2000 ).

\subsection{Fricatives}

The English fricatives include: / f, v, $\theta, \delta, \mathrm{s}, \mathrm{z}, \breve{\mathrm{s}}, \breve{\mathrm{z}}, \mathrm{h} /$. Again voiced fricatives can become devoiced finally (Yarmohammadi, 1995). The fortis (voiceless) fricatives have the effect of shortening the preceding vowel, as do fortis stops. /ž/ is of limited occurrence. /h/ has the quality of the vowel which follows it.

\subsection{Affricates}

The two affricate phonemes of English are $/ \check{c} /$ and $/ \mathrm{j} / . / \check{c} /$ is voiceless and fortis and thus it has the effect of shortening a preceding vowel in a final position. / $\mathrm{j} /$ is voiced and lenis and can become devoiced finally. /č/ like voiceless stops is slightly aspirated and unreleased in the same positions (Roach, 2000).

\subsection{Nasals}

$/ \mathrm{m}, \mathrm{n}, \mathrm{y} /$ are the nasals of English. $/ \mathrm{y} /$ in English, like its equivalent in Kurdish, is not regarded as a phoneme on the part of some authors (Roach, 2000). $/ \mathrm{y} /$ never occurs in initial positions or after a diphthong or a long vowel. $/ \mathrm{m} /$ and $/ \mathrm{n} /$ each have two allophones: syllabic and nonsyllabic.

\subsection{Laterals}

The /1/ is a lateral phoneme in English. The realization of /1/ before vowels is different from that found in other contexts. This creates two allophones of /1/: the clear [1] and the dark or velarized [í]. Clear [1] will occur before vowels only.

\subsection{Retroflexes}

The phoneme $/ \mathrm{r} /$ is a retroflex that during its production the tip of the tongue never actually makes contact with any part of the roof of the mouth. In English (RP) this phoneme only occurs before vowels (Roach, 2000).

\subsection{Semivowels}

There are two semivowels in English: /w/ and /y/. Both occur in all positions and they become voiceless (devoiced) and slightly fricative when preceded by the voiceless stops $/ \mathrm{p}, \mathrm{t}, \mathrm{k} /$. In American English they can occur as the second member of diphthongs.

\subsection{Consonant Clusters of Kurdish and English}

The syllable system of both Kurdish and English are that of the peak type: there are as many syllables as there are vowels. The syllable structure of Kurdish can be represented as (C) CV (C) (C) (C). This means that Kurdish permits clusters of three consonants finally and two consonants initially. It also shows that a syllable (at least) has one consonant and one vowel, but it cannot be a single vowel in isolation (Karimi, 1994). The syllable structure of English can be represented as (C) ( C) ( C) V (C) (C) ( C) ( C) phonemically. Thus, English 
permits up to three consonants in a cluster initially and four finally. It also shows that a syllable may be only a single vowel in isolation (Roach, 2000).

\section{Vowel System of Kurdish}

\subsection{Simple vowels}

There are eight simple vowels in Kurdish, five inherently long and three short vowels. They are:
1. $/ \hat{i} /$ as in
2. $/ \mathrm{e} /$ as in
žîr ( wise )
3. $/ \mathrm{i} /$ as in
žer ( under )
4. $/ \mathrm{a} / \quad$ as in
žin ( woman )
5. $/ \mathrm{a} / \quad$ as in
das ( hand )
6. $/ \hat{\mathrm{u}} /$ as in
dâs ( sickle )
7. $/ \mathrm{u} /$ as in
kûř ( bent)
8. $/ \mathrm{o} /$ as in
kuř ( boy )
kôr ( forum )

The vowel /i/ is almost like schwa in English and except for minute differences they can be regarded as the same; so it can be represented as /a / as well. Long vowels are shortened when they occur in a final position and are unstressed; this can be seen in the differences between the last û/ in hât û čû (he came and went) versus hât û čû (to come and go). The last / $\hat{\mathrm{u}} /$ in the latter example is shortened since it is word-final: it is even pronounced as hât û čô by most speakers. The high vowels specially /î/ and / $\hat{u} /$ are also shortened when they occur before two consonants: ?anûm (I sleep), but nustim (I slept) (Mc Carus, 1992). Vowels never occur in an initial position. /u/ and $/ \mathrm{i} /$ never occur in a final position.

\subsection{Diphthongs}

The sounds that are sometimes called diphthongs in Kurdish are really a simple vowel coming with one of the semivowels: / w, y /. In other words there is no glide from one vowel to another vowel in Kurdish. There are six kinds of these so-called diphthongs:

[ ey ] as in peynja ( ladder)

[ây ] as in čây ( tea )

[ ûy ] as in čûy ( you went)

[ ôy ] as in birôyn ( let's go )

[aw ] as in šaw ( night)

[ âw ] as in čâw ( eye )

\section{Vowel System of English}

\subsection{Simple vowels}

There are eleven simple vowels in English: five long and six short vowels. Furthermore there is another short sound (called schwa) which is always associated with weak syllables (Roach, 2000). The short vowels are /i, e, û, ó, $\mathrm{u} /$ and the long vowels are /î, â, $\hat{o}, \hat{u}, 3 /$. Vowels can have different variations based on their context. The distinction between short and long vowels is not so exact. The context (e.g. the sounds that follow vowels) and the presence or absence of stress are the major factors that determine the length of a vowel (Roach, 2000).

\subsection{Diphthongs}

There are totally eight diphthongs in English. They are /ai, ei, эi , iə, eə, uə, au, əu /. The diphthongs in English, unlike Kurdish, consist of a movement from one vowel to another vowel. The first part of a diphthong is much longer and stronger than the second part.

\section{Stress in Kurdish and English}

Among the factors that contribute to the prominence we perceive in a stressed syllable, pitch and length produce a strong effect in English while in Kurdish length has no prominent role and the strongest effect is made by loudness and pitch. Also a two-level analysis of stress (between stressed and unstressed syllables) suffices for Kurdish while in English there is a reference to one or more intermediate levels (Ladefoged, 2000; Roach, 2000). Furthermore, while Kurdish is a syllable-timed language (there is no strong pattern of stress and syllables maintain their quality), English is stress-timed (stress occurs at regular intervals).

\subsection{Stress in Kurdish}

Any Kurdish word which is more than one syllable is pronounced with one of its syllables being stressed and the rest unstressed. For some words a change in the position of stress results in a change either in the meaning of that word or a change in its grammatical status: barzî(you are tall) versus barzî (height). In a word the stress generally falls on the last syllable. Some morphemes, however, take stress (Jacub, 1993). Thus word stress is essentially morphological, a characteristic that is present in most Iranian languages e.g. Persian (Yarmohammadi, 1996). To summarize it can be said that in Kurdish:

1. Most of the words have their stress on their final syllable. 
2. Stem-final vowels are regularly stressed: hatin (they came) versus hatin (to come)

3. Some suffixes however, are stressed; so when they attached to other words they cause a shift in stress. Some of these suffixes include:

a. definite suffix -aka e.g. mindâl (child ) versus mindâlaka ( the child )

b. plural suffix -ân e.g. lâw ( a young man ) lâwân (young men )

c. comparative and superlative signals -tir and -tirîn e.g. pân ( wide ), pântirin ( the widest )

4. Negative prefixes on verbs are stressed: čûm (I went) versus načûm (I didn’t go).

5. In vocative case the initial syllable is stressed: mâmôsta (teacher) versus mâmôsta (teacher!).

6.The conjugation of verbs also causes some shifts in stress : nûsîn ( to write ), ?anûsim ( I write ), nûsîma ( I've written ).

7. Some most commonly used verb endings don't take stress and hence it is shifted to the first syllable of the word:

a. the ending -a ( it is ) : čâka ( goodness ) versus čâka ( it is good ), kâya (play ) versus kâya (It is straw).

b. the ending -î for the third person singular : girdî ( roundness ) versus girdî (He/she took it)

c. the ending -î for the second person singular : šetî ( madness ) versus šetî (You are mad)

8. Nominal compounds usually have their primary stress on the last element of the compound:

$\begin{array}{lll}\text { naxôš ( sick ) } & \text { xâna ( house ): } & \text { naxôšxâna ( hospital ) } \\ \text { dang ( sound ) } & \text { bâs ( discussion ): } & \text { dangubâs ( news ) } \\ \text { bîs ( twenty ) } & \text { hašt ( eight ): } & \text { bîsûhašt ( twenty eight ) }\end{array}$

9. In one-word sentences for simple tenses the stress is on the first syllable, in negative verbs it is on the negative element, in past perfect it is on the inflected form of bîn (to be), and in present perfect it is on the second syllable (Rokhzadi,2000) :

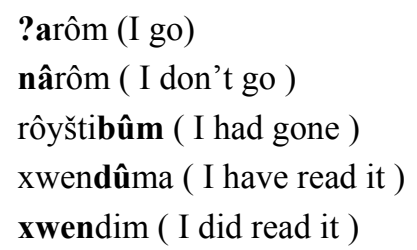

10. In sentences with direct object (in present tense) if the stress falls on the direct object, it refers to a habitual action, but if the stress falls on the verb, it refers to a present continuous action:

Kawan kâya ?akâ . (Kawan habitually plays)

Kawan kâya ?akâ. (Kawan is playing)

11. Adverbs seem to carry the primary stress:

?ewa hâtin (You came)

?ewa zû hâtin (You came soon)

12. In interrogative sentences the stress falls on the question word:

bô ačî? (Why do you go?)

7.2 Stress in English

It is very difficult to predict the place of stress in an English word and as Roach puts it "it is best to treat stress placement as a property of the individual word, to be learned when the word itself is learned" (Roach, 2000).

Within the framework of generative phonology, however, some scholars recently have tried to provide some general and practical rules to guess the placement of stress within words in English. The best examples in this area are the works of Dickerson (1989). To decide on word stress it is necessary to know the following information about the word: the phonological structure of the word, its part of speech, the number of syllables, and the phonological structure of the syllables (Roach, 2000).

Generally in an English word the stress falls on the strong syllable (one with a long vowel or a diphthong as its peak or with one or more consonants follow the peak). It also seems that in English there is a tendency to place stress near the beginning of the word (unlike Kurdish that it is usually at the end of the word). In compounds and phrases stress tends to fall on the head nouns. As for sentences it is generally agreed that the stress falls on the appropriate syllable of the last content word (Dickerson, 1989). It should also be noted that in English (like Kurdish) it is often the new information within a sentence that takes the sentence stress (Kelly, 2000). In the literature on the sound system of English one can find various lists of rules and generalizations for the placement 
of stress in English words (Dickerson, 1989; Roach, 2000), but it seems that exceptions to these rules somehow complicate the picture.

\section{Intonation in Kurdish and English}

Some syntactic information is conveyed by intonation in both English and Kurdish and most other Indo-European languages- not to mention information that is conveyed about the mood of the speaker- (Finch, 2000; Yarmohammadi, 1996). The variation of pitch creates intonation. The normal pitch of the speaker is called mid, the pitch higher than normal is called high, and lower than normal is named low. These are represented as 2 , 3 and 1 respectively. The high pitch is usually on the stronger stress. Some authors refer to four or five different tones: fall, rise, slight rise, fall followed by rise, and rise followed by fall (Richards, 2000).

An utterance may start with one of these levels and terminates with another or with the same level. This creates different intonation contours. An intonation contour is a pattern of pitch variation over the syllables of an utterance ending with one of the three falling, rising, and suspensive terminals that can be shown in notation by \#, // , / respectively. The numbers and bars provide a frame for comparing and contrasting intonation in Kurdish and English.

\subsection{Intonation in Kurdish}

A. 231\# This pattern is used in :

1) simple statements e.g. ?awân hâtin ( They came )

2) interrogative sentences with the question word in the middle of the sentence e.g. ?aw key cûu? ( When did he go?)

B. 31\# This pattern is used in :

1) declaration sentences with the strong stress on the first syllable of the sentence e.g. nâbe ?awân bizânin ( They shouldn't know )

2) interrogative sentences with the question word at the beginning of the sentence e.g. bô xwayân hâtin? (Why did they themselves come?)

C. 233// This pattern is used in :

1) a question with a statement word order, which is quite frequent in Kurdish e.g.?âzâd înglîzî ?azâne? (Azad Knows English?)

2) a question introduced by some particles like '?âxô', a near equivalent for auxiliary ( in function ) in inverted questions in English e.g. ?âxô ?awân ben ? (Do they come?)

D. 33// This pattern is used for changing a statement into question that usually begins with an auxiliary verb e.g. garakta bičî ? (Do you want to go?)

E. $232 /(2) 21 \#$ This pattern can be seen in these utterances :

1) an affirmative sentence composed of two clauses e.g. ?agar ?aw nahât / ?ewa bičin. (If he/she didn't come, you should go.) rôž kâr ?akâ šaw ?axafe. (He works during the day and sleeps at night.)

2) sentences with yâ na or choice questions e.g. ?âzâd nân ?axwâ yâ na? ( Is Azad eating or not ? )

F. 233/(2)33//. This pattern is present in :

1) interrogative complex sentences e.g. ?agar ?awân neyn / tô ?ačî ? (Will you go if they don’t come?)

2) a sentence with a tag question e.g.

?âzâd nân ?axwâ / wâ niya ? (Azad is eating, isn’t he?)

\subsection{Intonation in English}

This concise treatment of English intonation has been adopted from Yarmohammadi (1996) with some changes.

A. 231\#. This pattern is used in:

1) declarative simple sentences e.g. He went home.

2) declarative sentences containing auxiliary and reporting verbs followed by complements e.g. I don't know if it was Dr Johnson.

3) interrogative sentences containing question words e.g. Where did you get the lemon juice ?

B. 233//. This pattern is used in :

1) a question with a statement word order e.g. He went home? 
2) a question with a subject-auxiliary inversion e.g. Did he go home?

C. $232 /(2) 31 \#$. This used in:

1) an affirmative sentence composed of two clauses e.g.

I will get some for you / if you want me to.

Why don't we get together / and play tennis?

D. $232 /(2) 33 / /$. This pattern can be seen in :

tag questions asking for information e.g. He went home, didn't he?

\section{Data Collection}

Based on the similarities and dissimilarities of Kurdish and English sound systems (the International Phonetic Association, 1999; Kenworthy, 1999), following examples are some of the deviant productions collected from Kurdish learners who were learning English as a foreign language:

1. Aspiration of all English unaspirated voiceless stops.

2. Heavy palatalization of $/ \mathrm{k}, \mathrm{g} /$ before high vowels.

3. Pronouncing English alveolar sounds as dental-alveolar.

4. Substitution of Kurdish /s/ or /t/ for English / $/$ /.

5. Substitution of Kurdish /z/ or /d/ for English $/ \delta /$.

6. Strong palatalization of $/ \mathrm{t} / \mathrm{after}$ velarized $/ 1 /$.

7. Substitution of English $/ \mathrm{v} /$ by $/ \mathrm{w} /$.

8. Palatalization of $/ \mathrm{s} /$ in an initial position.

9. Palatalization of $/ \check{c} /$ and $/ \mathrm{j} /$ in almost all position.

10. Pronouncing the English trill $/ \mathrm{r} /$ as flap $/ \mathrm{r} /$ when it must be trill.

11. Substitution of English syllabic [m],[n] and [1] by Kurdish [im], [in] and [il]

12. Interpretation of English initial $\mathrm{CC}$ clusters as $\mathrm{CiC}$.

13. Substitution of Kurdish [Ciy] for English [Cy] in clusters like ty in tune.

14. Pronunciation of English $[\mathrm{sC}]$ as Kurdish [siC] in words like school.

15. Interpretation of English $\mathrm{CCC}$ clusters as $\mathrm{CiCC}$ or ?CCiC in words like spread and street.

16. Substitution of Kurdish /ô/ or/â/ for English /û/ in words like cup and some.

17. Substitution of Kurdish /â/ or /ô/ for English /ŏ/ in words like saw and hot.

18. Pronouncing the second element of diphthongs as a glide-either $/ \mathrm{y} / \mathrm{or} / \mathrm{w} /$ - rather than a vowel.

19. Pronouncing English vowels irrespective of their different durations in various contexts.

20. Placing primary stress of compounds on the last element so 'White House' may be pronounced as 'white house'.

21. Putting the sentence stress on the negative element within a sentence in a sentence like 'She doesn't go'.

22. Placing the sentence stress on the question word in an interrogative sentence in questions like 'Who went to the cinema?'

\section{Conclusion and Implications}

This concise comparison reveals the following generalizations for the sound systems of Kurdish and English. Kurdish has thirty consonant phonemes, English has twenty four. The phonemes $/ \mathrm{y}, \mathrm{w}, \mathrm{r}, \mathrm{l}, \eta, \mathrm{n}, \mathrm{m}, \mathrm{j}, \breve{\mathrm{c}}, \mathrm{f}, \mathrm{v}, \mathrm{s}, \mathrm{z}, \breve{\mathrm{s}}, \mathrm{z}, \mathrm{h}, \mathrm{p}, \mathrm{b}, \mathrm{t}, \mathrm{d}, \mathrm{k}, \mathrm{g} /$ are present in both Kurdish and English, though phonetically there are some differences with respect to their production and quality. The Kurdish phonemes /q, $,, ?, \gamma, \mathrm{x}, \hat{h}, \hat{l} /$ are absent in English, and English phonemes $/ \theta, \delta /$ are absent in Kurdish. The Kurdish / ř/ and $/ \hat{l} /$ are not present as phonemes in English, but as allophones of $/ \mathrm{r} /$ and $/ 1 /$. The number of vowel phonemes is twelve for English, whereas in Kurdish this number is eight. The vowels /û,ǒ, $3 /$ are not present in Kurdish. The vowel phonemes /î, ,a,a,a,ô,u,û,e/ are common in the two languages, ignoring some minor differences. Since Kurdish diphthongs are vowels followed by glides, it is true to say that diphthongs are not present in Kurdish, while English has eight diphthongs. Vowels are reduced to /a/ in unstressed syllables in English, while in Kurdish there is no reduction and this may lead to the full (strong) pronunciation of the English vowels that should be reduced to $/ \mathrm{\partial} /$.

Stress across the two languages demonstrates many fundamental differences. First, the nature of stress is different in the two languages: while stress is produced mainly by pitch in English, it is produced by loudness in Kurdish. Second, stress is predictable in Kurdish, while it is not so in English. Third, in English, stress tends to fall near the beginning of the word, whereas it often falls on the last syllable in a Kurdish word. Furthermore, 
stress influences the quality of vowels in English so the unstressed words are reduced to weak forms; however, in Kurdish this is not so. Finally, stress is the basis of rhythm in English, but in Kurdish it is the syllable that plays this role. As a raw conclusion it can be said that stress needs more time and energy in teaching English to Kurdish speakers.

The comparison and contrast of intonation across Kurdish and English reveals more similarities than stress. Intonation has the same function in the two languages: it conveys linguistic information about the syntactic structure of a sentence, whether it is a question or a statement, whether it is a simple sentence or it has some embedding parts and so on. It can also be concluded that in both Kurdish and English the level of pitch in beginning and terminating a sentence is much more important. Moreover, in both Kurdish and English questions are uttered with a rising intonation (except for information questions in English), statements with a falling intonation, and non-complete sentences with a suspensive intonation.

According to Fakhry Boskany (2002) teaching of English to speakers of Kurdish poses problems which can be attributed to the nature of both languages. Many problematic areas indeed arise in teaching of phonetics. This study which was an attempt to compare and contrast the sound systems of Kurdish and English will be of great and helpful significance for pedagogical aims.

The results of CA should be regarded as raw materials that have no direct use in the classroom. These results can be processed and used in preparing teaching materials or companion and complementary materials for the teaching of pronunciation, preparing pronunciation tests, and diagnosing areas that need much time and energy. Finally, it should be reiterated that neither all differences cause problems, nor all problems happen because of the differences.

\section{References}

Abdullah, S. \& Alam, K. (2004). English-Kurdish (Sorani) and Kurdish (Sorani)-Dictionary. India: Star publication/Languages of World Publication.

Asher, R \& Simpson, J (Eds.) The Encyclopedia of language and linguistics. Oxford: Pergamon Press.

Asher, R. \& Simpson, J. (Eds.). (1994). The encyclopedia of language and linguistics. Oxford: Pergamon Press.

Banathy, B.H., Trager, E.C. \& Waddle, C. D. (1966). The use of contrastive data in foreign language course development. Trends in modern language teaching. New York: Holt, Rinehart and Winston, Inc.

Bright, W. (Ed.). (1992). International encyclopedia of linguistics. Oxford: Oxford University Press.

Brown, H. D. (2000). Principles of language learning and teaching. London: Longman.

Chen, K. (1997). English vs Chinese: World views and writing styles. TESOL Matters. 7, 1-13.

Cook, G. (1999). Contrastive analysis. In K. Johnson and H. Johnson (Ed.), Applied linguistics (pp.85-87). Blackwell Publishers.

Di Pietro, R.J. (1971). Language structures in contrast. Newbury House Publishers.

Dickerson, W. (1989). Stress in the speech stream. Urbana: The University of Illinois Press.

Ellis, R. (2008). The study of second language acquisition. Oxford: Oxford University Press.

Fakhry Boskany, S.A. (2002). A contrastive analysis of agreement in standard English and standard Kurdish. Unpublished M.A. thesis. Sallahaddin University. Arbil, Kurdistan.

Fallahi, M. (1991). Contrastive linguistics and analysis of errors. Tehran: Iran University Press.

Fasold, R. W. \& Connor-Linton, J. (Eds.) (2006). An introduction to language and Linguistics. Cambridge: Cambridge University Press.

Finch, G. (2000). Linguistic terms and concepts. London: Macmillan Press.

Fries, C.C. (1945). Teaching and learning English as a foreign language. Michigan: University of Michigan Press.

Hartman, R. (1980). Contrastive textology. Heidelberg: Julius Groos. [Online] Available: http://en.wikipedia.org/wiki/kurdish_language.2010.

Ioup, G. (1984). Is there a structural foreign accent. Language Learning, 34:2, 1-17. doi:10.1111/j.1467-1770.1984.tb01001.x, http://dx.doi.org/10.1111/j.1467-1770.1984.tb01001.x

Jacub, J. A. (1993). On teaching the sound system of English in primary stage. Roshinbiri New (in Kurdish), 130, 79-93.

James, C. (1980). Contrastive analysis. London: Longman.

Johnson, K. \& Johnson, H. (Eds.) (1999). Encyclopedic dictionary of applied linguistics. London: Blackwell Publishers. 
Kaplan, R. (1966). Cultural thought patterns in intercultural education. Language Learning, 16, 1-20. doi:10.1111/j.1467-1770.1966.tb00804.x, http://dx.doi.org/10.1111/j.1467-1770.1966.tb00804.x

Karimi Doostan, GH. (1996). the phonemic system of the Kurdish dialect of Sanandaj. Linguistis (In Persian), (10)1, 55-62.

Kelly, G. (2000). How to teach pronunciation. London: Pearson Education.

Kenworthy, J. (1999). Teaching English pronunciation. New York: Pearson Education Limited.

Keshavarz, M.H. (1994). Contrastive analysis and error analysis. Tehran: Rahnama Publications.

Khaznadar, M. (2002). The History of the Kurdish literature (In Kurdish). Hawler: Aras Publications.

Kohler, K. (1971). On the adequacy of phonological theories for contrastive analysis. In G. Nickel (Ed.) Papers in contrastive linguistics. (pp. 83-88). Cambridge: Cambridge University Press.

Krzeszowski, T. P. (1974). Contrastive Generative grammar: Theoretical foundations. Lods University Press.

Ladefoged, P. (2000). A course in phonetics. New York: Harcourt, Brace Jovanovich.

Lado, R. (1957). Linguistics across culture: Applied linguistics for language teaching. Michigan: University of Michigan Press.

Mc Carus, E.N. (1992). Kurdish. In W. Bright (Ed.), International encyclopedia of linguistics. (pp. 289-294). Oxford: Oxford University Press.

Mirhassani, A. (1983). Pronunciation problems of Iranian students learning English. IRAL, 21:4, 320-330.

Mirhassani, A. (1989). Contrastive analysis of English and Persian verbs. IRAL, 27:4, 325-346.

Nabaz, J. (1976). The Unified language of Kurdish. (In Kurdish) Germany: The National Union of the Kurdish Students in Europe.

Nunan, D. (2001). Second language teaching and learning. Boston: Heinle \& Heinle Publishers.

Odlin, T. (1989). Language transfer. Cambridge: Cambridge University Press.

Ranta, G. (Ed.) (2010). Language education today: between theory and practice. Cambridge: Cambridge Scholars Publishing.

Richards, J.C. (1974). Error analysis: perspective on second language acquisition. London: Longman Group.

Richards, J.C. et al. (2000). Dictionary of language teaching and applied linguistics. London: Longman.

Ringbom, H. (1994). Contrastive analysis. In R. Asher \& J. Simpson (Eds.) The Encyclopedia of language and linguistics. Vol. 2. (pp. 737-742). Oxford: Pergamon Press.

Roach, P. (2000). English phonetics and phonology. Cambridge: Cambridge University Press.

Robins, R.H. (1997). A short history of linguistics. London: Longman.

Rokhzadi, A. (2000). Kurdish phonetics and grammar (in Persian). Tehran: Tarfand Publication.

Sajavaara, K. (1981). Contrastive linguistics: past and present and a communicative approach. In J. Fisiak (Ed.) Contrastive linguistics and the language teacher. (pp. Oxford: Pergamon Press.

Sanders, C. (1981). Recent developments in contrastive analysis and their relevance to language teaching. In J. Fisiak (ed.) Contrastive linguistics and the language teacher. (pp . 21-32.).Oxford: Pergamon Press.

Stren, H.H. (1983). Fundamental concepts of language teaching. Oxford: Oxford University Press.

The International Phonetic Association (1999). Handbook of the International Phonetic Association. Cambridge: Cambridge University Press.

Wais, GH.F. (1984). Phonetics. (In Kurdish). Baghdad: Al-Adib Press.

Wardhaugh, R. (1970). The contrastive analysis hypothesis. TESOL Quarterly, 4:2, 123-130. doi:10.2307/3586182, http://dx.doi.org/10.2307/3586182

Weinreich, V. (1953). Languages in contact. New York: Linguistic Circles of NY.

Yarmohammadi, L. (1995). Fifteen articles in contrastive linguistics and the structure of Persian. Tehran: Rhnama Publication.

Yarmohammadi, L. (1996). A contrastive phonological analysis of English and Persian. Shiraz: Shiraz University Press.

Yule, G. (2006). The study of language. Cambridge: Cambridge University Press. 